\title{
Thinking and exploration on Photovoltaic poverty alleviation model
}

\author{
Rui Ding \\ School of North China Electric Power University, Baoding 071000, China \\ m18833255708@163.com
}

Keywords: Photovoltaic poverty alleviation, Hemopoiesis type, Operation main body

\begin{abstract}
The year 2016 is the second year after the proposal of Photovoltaic poverty alleviation project. From the beginning of the photovoltaic poverty alleviation to now, the whole country has been vigorously promoting the photovoltaic project, however, the effect is uneven, and many difficult problems have emerged in the process of poverty alleviation. Starting from these problems, this paper expounds the reasons behind these problems, and puts forward some solutions and suggestions.
\end{abstract}

\section{Introduction: summary on photovoltaic poverty alleviation}

\subsection{Definition}

The so-called "Photovoltaic poverty alleviation" refers to laying solar panels on roofs of houses and agricultural greenhouses proposed on the basis of the rapid development of photovoltaic industry, "spontaneous production and use, redundant supplying on line". Solar energy, as a new energy, is rich in reserves and clean. Photovoltaic power generation is also considered to be one of the most promising ways to use energy, which has very rapid development. Especially in our country, PV industry started late, but, after over 20 years of development, it has achieved considerable size.

\subsection{Characteristics of photovoltaic poverty alleviation}

It is just on this basis that photovoltaic poverty alleviation has such advantages as strong sustainability, high stability, difficult to start, long duration as a new branch of the photovoltaic industry.

\section{Feasibility analysis on photovoltaic poverty alleviation}

On December 15, 2015, the 13th Five-Year plan on solar energy utilization (draft for comment) released by National Energy Board pointed out that Qinghai, Xinjiang and other places were rich in solar energy resources, large scale development area was available, thus, Million kilowatt class photovoltaic power generation bases were planed to construct. It proposed that comprehensive development of photovoltaic poverty alleviation projects were to be performed in national poverty counties with 1000 hours or above of solar annual utilization during "13th Five-Year" period, with 3 million poor households with recorded no labor ability covered, and brought at least 3000 years of cash income per household per year. Visible, photovoltaic poverty alleviation has been undergoing in the right.

The following table shows the annual PV installed capacity in China .

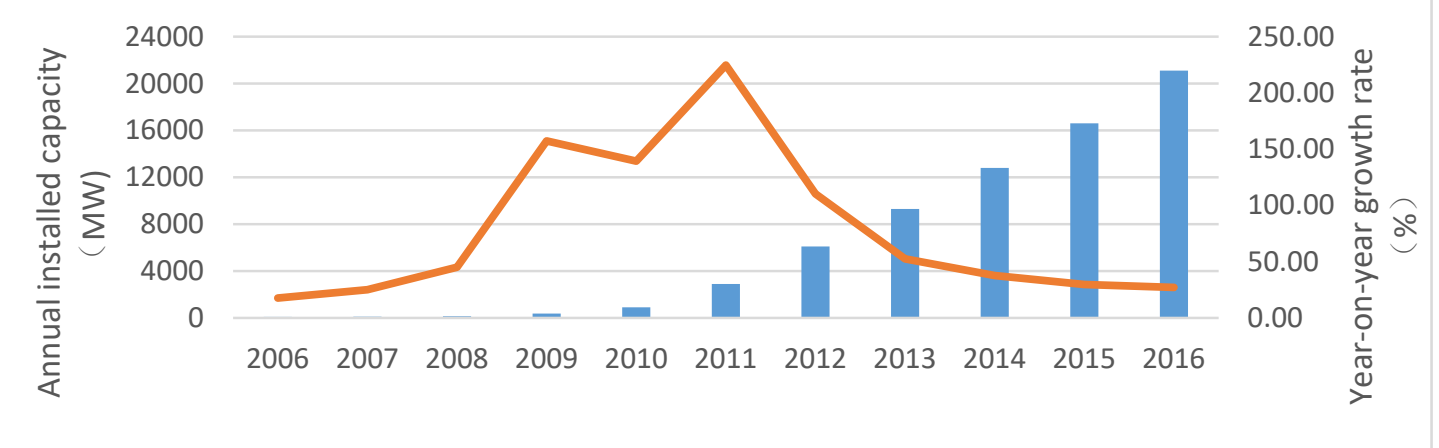


The photovoltaic power generation itself can also generate excellent economic benefits. Investigation work carried out has indeed made sure that the most needy families can get support and help, and poverty alleviation funds can also be transferred to every household in every village, this can really achieve accurate poverty alleviation.

Photovoltaic power generation also has environmental benefits. According to estimates, each 3 kW PV power station can reduce 45 tons of emissions of sulfur dioxide, carbon dioxide and other harmful gases caused by coal burning in 25 years. Due to the poor areas are surrounded by mountainous, so compared with the traditional poverty alleviation projects, the cleanliness of Photovoltaic poverty alleviation enables it to protect the local ecological environment while bringing benefits.

\section{Problems existing in photovoltaic poverty alleviation}

\subsection{PV industry development requiring guidance}

After nearly 20 years of rapid development, China's photovoltaic industry now has a certain scale. However, the same as traditional industries, Photovoltaic industry development issues are reflected in the excessive dependence on investment driven and low-end competition. Of course, this is related to fixed assets investment as the main means of stimulating economic growth since China's reform and opening up. And ultimately these problems are reflected in: on the one hand, the blind growth of capital has led to overcapacity in the PV industry, coupled with local governments tend to blind support for emerging industries, the whole industry shows a deformed state of development; on the other hand, when focusing on low-end competition, it ignores the enhancement of capability of independent research and development, which results in China's photovoltaic industry core technology have a high dependence on foreign countries.

\subsection{Financing problem in the early stage of the PV poverty alleviation}

The initial investment of photovoltaic power plants is very large, and although there is a stable income, the return cycle is still long. Although the government and enterprises will provide some of the subsidies, but poor families still have to pay a lot of money. For state and local governments, the funding is clearly limited; on the other hand, if too much investment is required from enterprises, this is contradictory to the nature of the company's earnings, so it is not practical to urge companies to invest. Therefore, there are difficulties in the early stage of the financing of photovoltaic projects.

\subsection{Operation and maintenance issues in the middle and late stage of PV poverty alleviation projects}

On given issues of cost and local employment development, operation and maintenance of photovoltaic power plants in the middle-later period are often completed by the residents themselves. However, the operation and maintenance of PV power station generally unavoidably involves many professional knowledge if lacking professional guidance, it is likely to have some non-standard operations, and cause damages on equipment, shortened life and other losses, thus, the photovoltaic poverty alleviation effect will be greatly reduced. Especially in poor areas, the economy is not developed, the overall cultural level of the masses is low, the power grid infrastructure is weak, there will be many problems. But, if the operation and maintenance by the professionals, it will increase a lot of cost. Thus, the problems on operation and management of photovoltaic poverty alleviation in the middle-later period can not be ignored.

\subsection{Other issues}

There are some other problems in the project, such as the allocation of funds. The most direct way of evaluation of the effectiveness of a poverty alleviation project is how much benefits will be gained by residents. How to eliminate corruption in the allocation of funds has also become a problem. In addition, photovoltaic power plants are also involved in the safety problems, especially when the operation is not standardized, it is very likely to have an accident. 


\section{Conlusion}

\subsection{Industry development}

If there is no good industrial development as a support, photovoltaic poverty alleviation is bound to be short-lived. According to the present situation of the development of photovoltaic industry in China, the following suggestions are proposed:

1) To promote the transformation of photovoltaic enterprises. To enhance the ability of independent innovation of photovoltaic technology, reduction on costs can improve the competitiveness.

2) To deepen the reform of the system. From the government concerned, to reduce the intervention to strengthen the guidance to avoid government investment impulse, resulting in excess capacity; From the market, to build a fair electricity market to promote the development of new energy.

3) To standardize industry standard. As known, China's photovoltaic industry started late, timely development of industry standards can not only avoid vicious competition between enterprises, but also guide the healthy development of the industry

\subsection{Operation main body}

Obviously, companies and governments are not suitable as the main body of photovoltaic poverty alleviation. Well, according to the precedents, charity foundation is undoubtedly a good subject. Charitable foundation refers to nonprofit Corporation for being engaged in public welfare undertakings established on law by property donated by natural persons, legal persons or other organizations. If the government can launch Foundation to accept donations from all walks of life, as well as government subsidies and corporate profits, money is not a problem, on the other hand, it can also enhance the recognition of photovoltaic poverty alleviation in the community.

During the introduction of the foundation, other problems of fund allocation and post operation \& maintenance can also be solved. That is, as the main body, the foundation can play a leading role in all aspects of photovoltaic poverty alleviation: in the initial period, it can be responsible for leading, financing; in the middle-late period, responsible for professional operation and maintenance management, as well as a regulatory role in the allocation of funds, so that the overall poverty alleviation effect will achieve the best.

\section{Reference}

[1] Ruan X K.When the PV encounters poverty alleviation.Frontier observation, 011, 2016.

[2] Xu C X.Photovoltaic Poverty Alleviation -- support of getting rid of poverty.Frontier observation, 013, 2016.

[3] Wang G F, Zheng Y.Trend of Photovoltaic poverty alleviation.Photovoltaic industry. 003, 2016

[4] Wei Z, Yu B Q.Current situation and Countermeasures of photovoltaic industry development in China.Alternative energy and new energy, 006, 2013. 